\title{
Juvenile Wood from Pinus patula Schltdl \& Cham for Multilaminated Panel Production
}

\author{
Everton Lorenzett Tavares ${ }^{1}$, Everton Hillig ${ }^{1}$ (D), Andrea Nogueira Dias ${ }^{1}$, \\ Antonio José Vinha Zanuncio ${ }^{2}$, Edson Luis Serpe ${ }^{1}$ \\ ${ }^{1}$ Programa de Pós-graduação em Ciências Florestais, Universidade Estadual do Centro-Oeste - UNICENTRO, \\ Irati/PR, Brasil \\ ${ }^{2}$ Curso de Engenharia Florestal, Universidade Federal de Uberlândia - UFU, Monte Carmelo/MG, Brasil
}

\begin{abstract}
Wood scarcity, attacks by primates and insects, and fungal damage in forest plantations make the introduction of new species necessary. Given this, it is important to understand the potential uses of wood in the production chain. Pinus patula Schltdl \& Cham presents good adaptation to Brazilian conditions and is a candidate for wood supply. Its juvenile wood density however, is lower than that of other pine species. This study aimed to evaluate the properties of veneer on panels produced with twelve-year old $P$. patula wood compared with panels produced with $P$. taeda wood of the same age, which is commonly used for panel production. Panels were bonded with urea-formaldehyde and phenol-formaldehyde adhesives using veneers applied on two types of plywood panel. The P. patula panels showed lower strength, stiffness and density when bonded with urea-formaldehyde, and higher strength, density and stiffness when bonded with phenol-formaldehyde in comparison with P. taeda. P. patula panels can be used for multilayer panel production.
\end{abstract}

Keywords: phenol-formaldehyde, urea-formaldehyde, Pinus taeda, plywood, veneers. 


\section{INTRODUCTION}

In Brazil, the plywood sector has an established production capacity of over 4 million cubic meters, with $74 \%$ of the total being exported (Vieira et al., 2012). Approximately $70 \%$ of the plywood panels are produced with pine wood, such as Pinus taeda L. and Pinus elliottii Engelm. The wood of these trees is in high demand, making the consideration of other species for panel production necessary (Iwakiri et al., 2012).

Sapajus nigritus damages P. taeda plants in Paraná and Santa Catarina state, leading to reduced wood production (Liebsch et al., 2018). There is no efficient control method for S. nigritus, such that alternative plant species may be able to mitigate this problem.

Pinus patula Schltdl \& Cham is native to the Mexican mountains, in Sierra Madre Oriental and is one of the most exploited species in the country (Sánchez-González, 2008; Van Zonneveld et al., 2009). Its species grow up to $12.6 \mathrm{~m}^{3} / \mathrm{ha} /$ year by twelve years of age (Santiago-García et al., 2015). In Brazil, P. patula is planted in southeast Minas Gerais, northeast São Paulo, west Santa Catarina and in the mountains of Rio Grande do Sul with wood productivity higher than P. taeda (Aguiar et al., 2014). There is no record of $S$. nigritus damage to Pinus patula trees.

In Brazil, pine plantations have suffered a reduction in their forest rotation, undergoing two thinnings, the first at eight years and the second between 12 and 13 years, and clear cutting between 19 and 20 years (Folmann et al., 2014). Thus, it is important to evaluate the possibilities of using wood from younger trees, such as the 12 year-old trees used in this study.

It was found that $P$. elliottii showed a variation of wood density in the radial direction that allowed the categorization of its wood by means of this characteristic, as either juvenile or adult. This variation was similar to that found by other researchers for P. patula and $P$. taeda, showing that for these species juvenile wood occurred until the 5th growth ring and the adult wood after the 14th ring in relation to the pith (Palermo et al., 2013). Thus, the wood used in this study was considered juvenile and transition.

According to Vieira et al. (2012), the consolidation of the plywood industry occurred in 1965, with one of the driving factors being the development of urea-formaldehyde and phenol-formaldehyde resins, which gave plywood panels a more efficient bonding, providing humidity resistance between the veneers. This development allowed for their use in external environments, or in internal environments with the presence of high humidity.

The construction principles used in plywood panel manufacture aim to balance the physical-mechanical variation of the veneers' adjacent layers, arranged in the longitudinal and perpendicular direction to the panel plane. Balancing of plywood panels can be achieved with an even or odd number of veneers, but for that, the layers of their structural composition should always be in odd numbers (Ross, 2010). Different structural compositions consist in the addition or arrangement of the veneers in alternation or in the same direction, in relation to the surface veneer, reinforcing the area that suffers greater structural demands under bending.

Thus, other principle construction compositions such as laminated veneer lumber (LVL) could be used for plywood panels. LVL are parallel veneer panels used as a structural component in buildings, especially in countries where there is a tradition of using wood in construction systems (Müller et al., 2015). According to Wilson \& Dancer (2005), in southeastern regions of the U.S., LVL panels are produced with Pinus elliottii or Pinus taeda wood, hot-pressed with phenol-formaldehyde adhesive. The veneers generally have 2.54 or $3.18 \mathrm{~mm}$ and LVL can vary in thickness and width but is most commonly produced with the dimensions $4.45 \mathrm{~cm}$ thick and $121.9 \mathrm{~cm}$ wide, with lengths of $18.29 \mathrm{~m}$. After being cut into narrower dimensions, they are currently used as an alternative to structural timber for headers and beams and as flanges in "I" composite beams.

Although LVL panels have specific production conditions for structural applications, the type of arrangement used in these parallel veneer panels could also be used in the plywood panel industry for specific purposes. An example would be small pieces that are supported only on the longest sides, thus requiring greater bending effort in this direction. Further, for indoor use, they can be glued with other types of non-waterproof adhesives. Aydin et al. (2004) used urea-formaldehyde and PVA to bond LVL panels made from Eucalyptus camaldulensis and Fagus orientalis woods, while Melo \& Del Menezzi (2014) produced and evaluated the properties of LVL panels made from Schizolobium amazonicum and PVAc adhesive. 
Purba et al. (2019) also produced and evaluated the properties of LVL panels made from secondary quality hardwood and PVAc adhesive.

Multi-laminated panel production, using perpendicular or parallel veneer arrangements, could be a viable alternative to $P$. patula wood use, due to good results from $P$. taeda plywood (Iwakiri et al., 2012; Müller et al., 2015). This study aimed to evaluate the $P$. patula multilayered wood panel quality produced with urea-formaldehyde and phenol-formaldehyde adhesives with veneers arranged in perpendicular and parallel on timber panels.

\section{MATERIAL AND METHODS}

\subsection{Biological material}

Eighteen trees each were harvested for $P$ patula and $P$. taeda (reference species), with diameters (DHB) ranging from 17 to $33 \mathrm{~cm}$. Nine trees were used for panel production and nine for wood basic density evaluation.

Twelve-year-old trees from both species were harvested in General Carneiro, Paraná state, Brazil

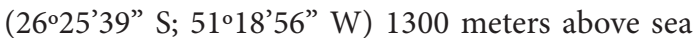
level. Data from a weather station located $5 \mathrm{~km}$ from the study area indicated average annual precipitation of $1776 \mathrm{~mm}$, the occurrence of frost between May and September and temperate climate according to Köppen classification.

\subsection{Wood basic density}

The wood basic density was determined by the ratio between dry mass and saturated volume, according to NBR-11941. Discs were removed from the base $(0.10 \mathrm{~m}), \mathrm{DHB}$ (1.3 meter high), at 25,50 and $70 \%$ of the total tree height.

\subsection{Lamination, drying and sorting}

The trees used for lamination were cut into $2.75 \mathrm{~m}$ long logs, and those with a diameter at the thin point equal to or greater than $17 \mathrm{~cm}$ were laminated. The number of rolled logs from each tree was recorded and the relative height at which each tree could be laminated was calculated.
Veneers with $600 \times 600 \mathrm{~mm}$ and $2.2 \mathrm{~mm}$ thickness were produced from P. patula and P. taeda trees and their quality was evaluated according to NBR ISO 2426-1 and 2426-3 and ABIMCI technical parameters (ABIMCI, 2002). The A and B class surface covers and the $\mathrm{C}+, \mathrm{C}$ and $\mathrm{D}$ Classes were used for the core in multilayered panels, according to ABIMCI classifications.

\subsection{Panel production}

The panels of each species were produced with two adhesive types and the seven veneers arranged according Figure 1. The adapted parallel arrangement (referred to in this study as Parallel Veneer Panel - PVP) was realized to facilitate the glue line shear strength test between this veneer and the adjacent one, allowing the evaluation of this mechanical property using the standard plywood test.

Since the plywood glue line shear strength test is performed on veneers that are arranged perpendicular to each other, this adaptation has allowed the same test to be used on the innermost glue line for both panel arrangements, making it possible to compare this property between the panels produced with the two types of arrangements.

On the other hand, the panel central veneer in perpendicular arrangement caused minimal influence on the panel bending strength, or elasticity modulus, (perpendicular $\mathrm{x}$ parallel direction) because its inertia moment is minimal and, therefore, caused minimal influence on bending properties.
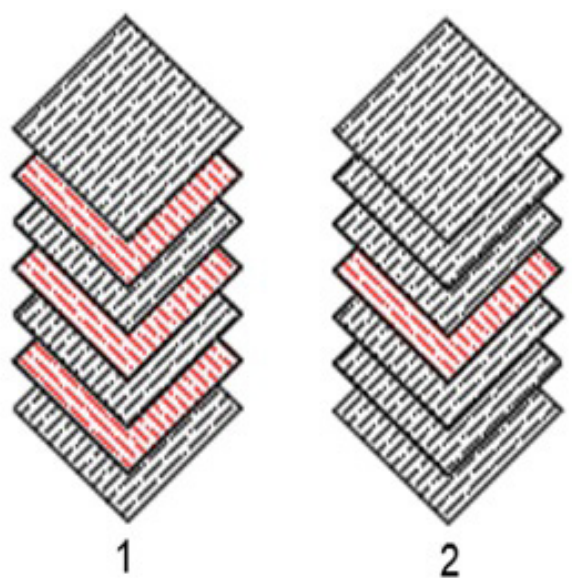

Figure 1. Veneer composition in panels. 1. Typical plywood; 2 adapted PVP. 
Three panels per treatment were produced with P. patula and P. taeda, applying two types of adhesives (Urea-formaldehyde - UF and Phenol-formaldehyde - PF), and two veneer arrangements, totaling eight panel types (Table 1).

Seven-layer plywood panels of $600 \times 600 \mathrm{~mm}$ were pressed in the heated hydraulic laboratory press. For UF and PF adhesives, the glue spread was $160 \mathrm{~g} / \mathrm{m}^{2}$ based on wet mass with the adhesive properties and glue compositions complying with the technical parameters (Table 2). Ammonium sulfate was also used as a catalyst at a $2 \%$ ratio in the urea-formaldehyde glue composition.

The pressing process occurred with $12 \mathrm{kgf} / \mathrm{cm}^{2}$ for 15 minutes at $110^{\circ} \mathrm{C}$ for urea-formaldehyde and $140^{\circ} \mathrm{C}$ for phenol-formaldehyde. The resulting panels had a $13.5 \mathrm{~mm}$ nominal thickness and were conditioned in a climatic chamber according to NBR-9489 recommendations.

The properties of multilaminated panels were evaluated based on plywood ABNT standards for both types of panels produced. This option of standards for both the panel veneer compositions, made their comparison possible and fulfilled study objectives. Additionally, it was found that prior studies involving LVL panels were carried out and evaluated by means of physical and mechanical properties traditionally used for plywood panels. (Tenorio et al., 2011; Guimarães et al., 2015; Mendoza et al., 2017).

The apparent density (NBR-9485), moisture content (NBR-9484), water absorption (NBR-9486), thickness swelling (NBR-9535), static bending in parallel and perpendicular directions (NBR-9533) and bond quality (NBR-ISO-12466/1 and NBR-ISO-12466/2) after wet treatment were evaluated for both adhesives and after boiling for phenol-formaldehyde.

\subsection{Statistical analysis}

The variance homogeneity (Bartlett's test at 95\% significance) and normality test (Shapiro Wilk test at $95 \%$ significance) were performed. The means per panel type were analyzed by variance analysis and Tukey test at 95\% significance.

\section{RESULTS}

\subsection{Wood basic density}

The wood basic density varied from 320 to $400 \mathrm{~kg} / \mathrm{m}^{3}$ and 300 to $350 \mathrm{~kg} / \mathrm{m}^{3}$ for P. taeda and P. patula, respectively, depending on trunk height (Figure 2).

Table 1. Panels produced according to the experimental design.

\begin{tabular}{cccc}
\hline Panel & Adhesive & Composition & Species \\
\hline 1 & urea-formaldehyde & Plywood & Pinus taeda \\
2 & urea-formaldehyde & Plywood & Pinus patula \\
3 & urea-formaldehyde & PVP & Pinus taeda \\
4 & urea-formaldehyde & PVP & Pinus patula \\
5 & phenol-formaldehyde & Plywood & Pinus taeda \\
6 & phenol-formaldehyde & Plywood & Pinus patula \\
7 & phenol-formaldehyde & PVP & Pinus taeda \\
\hline 8 & phenol-formaldehyde & PVP & Pinus patula \\
\hline
\end{tabular}

$\mathrm{PVP}=$ parallel veneer panel.

Table 2. Physical-chemical adhesive characteristics and glue composition.

\begin{tabular}{|c|c|c|c|c|c|c|c|c|}
\hline Parameters & \multicolumn{4}{|c|}{ Urea-formaldehyde } & \multicolumn{4}{|c|}{ Phenol-formaldehyde } \\
\hline Solid content $\left(1 \mathrm{~g} / 3 \mathrm{~h} / 105^{\circ} \mathrm{C}\right)$ & \multicolumn{4}{|c|}{$64-66 \%$} & \multicolumn{4}{|c|}{$48-51 \%$} \\
\hline Viscosity $\left(25^{\circ} \mathrm{C}\right)$ & \multicolumn{4}{|c|}{$300-1000 \mathrm{cP}$} & \multicolumn{4}{|c|}{$400-800 \mathrm{cP}$} \\
\hline $\mathrm{pH}$ & \multicolumn{4}{|c|}{$7.4-9.0$} & \multicolumn{4}{|c|}{$11.5-13.0$} \\
\hline Density $\left(25^{\circ} \mathrm{C}\right)$ & \multicolumn{4}{|c|}{$1250-1300 \mathrm{~kg} / \mathrm{m}^{3}$} & \multicolumn{4}{|c|}{$1190-1250 \mathrm{~kg} / \mathrm{m}^{3}$} \\
\hline Glue composition & $\begin{array}{l}\text { AP } \\
(\%)\end{array}$ & $\begin{array}{l}\text { WF } \\
(\%)\end{array}$ & $\begin{array}{c}\mathrm{H}_{2} \mathrm{O} \\
(\%)\end{array}$ & $\begin{array}{l}\text { SC } \\
(\%)\end{array}$ & $\begin{array}{l}\text { AP } \\
(\%)\end{array}$ & $\begin{array}{l}\text { WF } \\
(\%)\end{array}$ & $\begin{array}{c}\mathrm{H}_{2} \mathrm{O} \\
(\%)\end{array}$ & $\begin{array}{l}\text { SC } \\
(\%)\end{array}$ \\
\hline & 40 & 30 & 30 & 25 & 69 & 13 & 18 & 35 \\
\hline
\end{tabular}

Notes: pH: hydrogen potential; cP: centipoise; AP: adhesive; WF: wheat flour; $\mathrm{H}_{2} \mathrm{O}$ : water; $\mathrm{SC}$ : solid content. 


\subsection{Panel physical properties}

The panel density ranged from 426 to $542 \mathrm{~kg} / \mathrm{m}^{3}$; equilibrium moisture from 10.38 to $11.05 \%$; thickness from 12.90 to $13.88 \mathrm{~mm}$; water absorption from 95 to $101 \%$, thickness swelling from 6.37 to $9.53 \%$ and swelling plus recovery from 2.30 to $3.94 \%$ (Table 3).

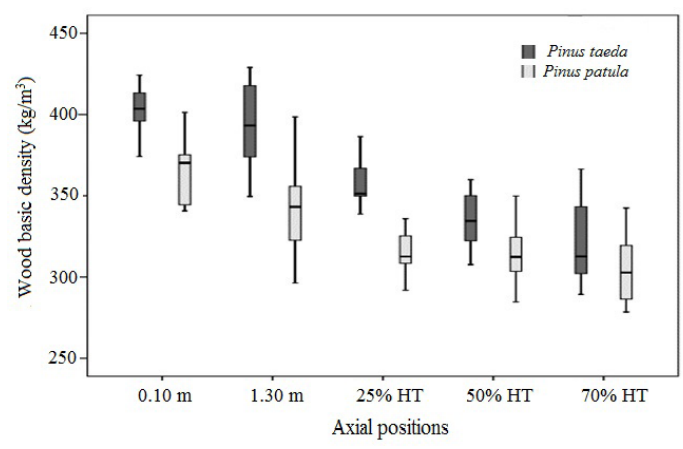

Figure 2. Pinus patula and Pinus taeda wood basic density $\left(\mathrm{kg} / \mathrm{m}^{3}\right)$ in different axial positions.

\subsection{Panel mechanical properties}

The mechanical property values in the different types of panels produced varied as a function of species, adhesive and composition (Table 4).

\section{DISCUSSION}

\subsection{Wood basic density}

The base of P. patula and P. teada presented higher basic density than the top. Cells with higher lumen and thinner wall are produced during the initial cambium activity (in the top) resulting in low basic density. However, this tendency is reversed with cambium maturation, generating cells with thicker cell walls, which increases the basic density. The wood produced during the cambium mature stage presents better quality for panel production (Vidaurre et al., 2011).

ABIMCI (2002) recommends that pine plywood panels have an apparent density of $517 \mathrm{~kg} / \mathrm{m}^{3}$ and a

Table 3. Panel physical properties.

\begin{tabular}{cccccccccc} 
Panel & Adhesive & PC & Species & $\begin{array}{c}\text { AD } \\
\left(\mathbf{k g} / \mathbf{m}^{3}\right)\end{array}$ & $\begin{array}{c}\text { EMC } \\
(\%)\end{array}$ & $\begin{array}{c}\text { Th } \\
(\mathbf{m m})\end{array}$ & $\begin{array}{c}\text { WA } \\
(\%)\end{array}$ & $\begin{array}{c}\text { TS } \\
(\%)\end{array}$ & $\begin{array}{c}\text { SPR } \\
(\%)\end{array}$ \\
\hline 1 & UF & Plywood & P. taeda & $542 \mathrm{c}$ & $10.78 \mathrm{ab}$ & $13.83 \mathrm{a}$ & $95 \mathrm{a}$ & $9.53 \mathrm{~b}$ & $3.94 \mathrm{a}$ \\
\hline 2 & UF & Plywood & P. patula & $458 \mathrm{ab}$ & $10.81 \mathrm{ab}$ & $13.45 \mathrm{a}$ & $104 \mathrm{a}$ & $6.37 \mathrm{a}$ & $2.91 \mathrm{a}$ \\
\hline 3 & UF & PVP & P. taeda & $526 \mathrm{c}$ & $10.75 \mathrm{ab}$ & $13.88 \mathrm{a}$ & $97 \mathrm{a}$ & $6.98 \mathrm{ab}$ & $2.43 \mathrm{a}$ \\
\hline 4 & UF & PVP & P. patula & $430 \mathrm{ab}$ & $11.05 \mathrm{~b}$ & $13.67 \mathrm{a}$ & $101 \mathrm{a}$ & $6.39 \mathrm{a}$ & $2.40 \mathrm{a}$ \\
\hline 5 & FF & Plywood & P. taeda & $453 \mathrm{ab}$ & $10.64 \mathrm{ab}$ & $13.06 \mathrm{a}$ & $99 \mathrm{a}$ & $8.93 \mathrm{ab}$ & $2.30 \mathrm{a}$ \\
\hline 6 & FF & Plywood & P. patula & $472 \mathrm{~b}$ & $10.40 \mathrm{a}$ & $13.27 \mathrm{a}$ & $100 \mathrm{a}$ & $8.20 \mathrm{ab}$ & $2.93 \mathrm{a}$ \\
\hline 7 & FF & PVP & P. taeda & $426 \mathrm{a}$ & $10.56 \mathrm{a}$ & $13.03 \mathrm{a}$ & $99 \mathrm{a}$ & $7.50 \mathrm{ab}$ & $2.37 \mathrm{a}$ \\
\hline 8 & FF & PVP & P. patula & $471 \mathrm{~b}$ & $10.38 \mathrm{a}$ & $12.90 \mathrm{a}$ & $101 \mathrm{a}$ & $7.72 \mathrm{ab}$ & $3.11 \mathrm{a}$ \\
\hline
\end{tabular}

Notes: PC: Panel composition; AD: Apparent density $\left(\mathrm{kg} / \mathrm{m}^{3}\right)$; EMC: Equilibrium moisture content (\%); Th: thickness $(\mathrm{mm})$; WA:Waterabsorption(\%);TS:Thicknessswelling(\%);SPR:Swellingplusrecovery(\%);UF:Urea-formaldehyde;FF:Phenol-formaldehyde; PVP: parallel veneer panel.

Table 4. Panel mechanical properties.

\begin{tabular}{|c|c|c|c|c|c|c|c|c|c|c|c|}
\hline \multirow{2}{*}{$\begin{array}{c}\text { Pan- } \\
\text { el }\end{array}$} & \multirow[t]{2}{*}{ Ad } & \multirow[t]{2}{*}{ PC } & \multirow[t]{2}{*}{ Species } & \multirow{2}{*}{$\begin{array}{c}\text { MOR // } \\
(\mathrm{MPa})\end{array}$} & \multirow{2}{*}{$\begin{array}{c}\text { MOR } \perp \\
(\mathrm{MPa})\end{array}$} & \multirow{2}{*}{$\begin{array}{c}\mathrm{MOE} / / \\
(\mathrm{MPa})\end{array}$} & \multirow{2}{*}{$\begin{array}{c}\mathrm{MOE} \perp \\
(\mathrm{MPa})\end{array}$} & $\begin{array}{c}\text { GL } \\
(\mathrm{MPa})\end{array}$ & $\begin{array}{l}\text { WF } \\
(\%)\end{array}$ & $\begin{array}{c}\text { GL } \\
(\mathrm{MPa})\end{array}$ & $\begin{array}{l}\text { WF } \\
(\%)\end{array}$ \\
\hline & & & & & & & & \multicolumn{2}{|c|}{ Wet } & \multicolumn{2}{|c|}{ Boil } \\
\hline 1 & UF & Plyw & P. taeda & $39.7 \mathrm{ab}$ & $26.4 b$ & $5131 \mathrm{a}$ & $2300 \mathrm{~b}$ & $1.00 \mathrm{a}$ & 20 & --- & --- \\
\hline 2 & UF & Plyw & P. patula & $33.9 \mathrm{a}$ & $27.3 b$ & $4689 a$ & $2732 b$ & $0.97 \mathrm{a}$ & 20 & --- & --- \\
\hline 3 & UF & PVP & P. taeda & $48.9 \mathrm{bc}$ & $6.4 \mathrm{a}$ & $6867 b$ & $343 a$ & $1.02 \mathrm{a}$ & 20 & --- & --- \\
\hline 4 & UF & PVP & P. patula & $40.7 \mathrm{ab}$ & $4.1 \mathrm{a}$ & $4681 a$ & $266 a$ & $0.98 \mathrm{a}$ & 20 & --- & --- \\
\hline 5 & $\mathrm{PF}$ & Plyw & P. taeda & $40.1 \mathrm{ab}$ & $25.1 \mathrm{~b}$ & $5864 \mathrm{ab}$ & $2254 b$ & $1.01 \mathrm{a}$ & 30 & $0.90 \mathrm{a}$ & 25 \\
\hline 6 & PF & Plyw & P. patula & $54.7 \mathrm{c}$ & $27.8 \mathrm{~b}$ & $7136 b$ & $2278 b$ & $0.99 a$ & 30 & $0.78 \mathrm{a}$ & 20 \\
\hline 7 & PF & PVP & P. taeda & $48.1 b c$ & $4.8 \mathrm{a}$ & $7139 b$ & $292 a$ & $1.01 \mathrm{a}$ & 30 & $0.82 \mathrm{a}$ & 20 \\
\hline 8 & PF & PVP & P. patula & $54.7 \mathrm{c}$ & $5.1 \mathrm{a}$ & $7136 b$ & $305 a$ & $0.89 a$ & 30 & $0.84 \mathrm{a}$ & 20 \\
\hline
\end{tabular}

Notes: Ad: adhesive; PC: Panel composition; MOR: Modulus of rupture (MPa); MOE: Modulus of elasticity (MPa); GL: glue line shear strength (MPa); WF: Wood Failure (\%); UF: Urea-formaldehyde; PF: Phenol-formaldehyde; Plyw: plywood; PVP: parallel veneer panel. 
maximum humidity of $11 \%$. Considering an average wood shrinkage of $0.53 \%$ per moisture content percentile for both pine species used, and a panel compaction of $10 \%$, an ideal basic wood density of approximately $445 \mathrm{~kg} / \mathrm{m}^{3}$ is estimated. Therefore, the range of basic density variation for both species was considered low for panel production. The disadvantage of this is greater veneer compaction during pressing. On the other hand, soft woods can facilitate the lamination process (Almeida et al., 2014).

\subsection{Panel physical properties}

The P. patula and P. taeda panel apparent density bonded with phenol-formaldehyde was lower than the $517 \mathrm{~kg} / \mathrm{m}^{3}$ required by quality standards. However, all panels showed equilibrium moisture content and nominal thickness variation lower than the 11 and $+/-5 \%$ maximum limit suggested (ABIMCI, 2002).

Average panel thickness was $13 \%$ less than the sum of the veneer thicknesses used, showing that there was veneer compaction. Costa \& Del Menezzi (2017) verified that different densification strategies caused an increase in the mechanical properties of plywood produced with paricá wood of density similar to P. Patula and P. taeda.

There are no normative standards for dimensional stability properties, however, the thickness swelling values for five tropical pinus species bonded with urea-formaldehyde for plywood production ranged from 5.06 to $7.09 \%$ and swelling plus recovery from 1.68 to $2.89 \%$ (Iwakiri et al., 2001), lower than those in this study.

Pinus plywood may present water absorption close to 60\% (Almeida et al., 2013; Silva et al., 2012; Campos et al., 2009), lower than those observed in this study. This difference is due to low wood density of both species used and the veneer thickness of $2.2 \mathrm{~mm}$. The adhesive type did not influence water absorption.

Panel swelling occurs due to the release of internal stresses during the pressing process (Iwakiri et al., 2001). The lower wood density of both species results in greater compaction. The panels were formed with seven $2.2 \mathrm{~mm}$ veneers, but their final thickness ranged from 12.90 to $13.88 \mathrm{~mm}$, causing internal stresses. These tensions are released during water absorption, following which, the panel does not return to its original state. Therefore, this study is able to explain thickness swelling and swelling plus recovery values.

\subsection{Panel mechanical properties}

The plywood panel presented averages for modulus of rupture (MOR) and modulus of elasticity (MOE), both parallel and perpendicular, above the minimum of $25.79 / 18.04 \mathrm{MPa}$ and $4735 / 2220 \mathrm{MPa}$, respectively, stipulated by ABIMCI (2002). Also, the glue line shear strength values under wet conditions were higher than the 0.88 for shear strength and $20 \%$ for wood failure, required by ABIMCI (2002)

Plywood panels produced with five tropical pine species, between 20 and 25 years old, showed parallel MOR and MOE values ranging from 58 to $102 \mathrm{MPa}$ and 6,300 to 13,714 MPa, respectively (Iwakiri et al., 2012), higher than those of this study. This difference occurred due to the juvenile wood use, since the trees in this study were 12 years old.

The P. elliottii wood showed juvenile wood up to the 7th growth ring and mature wood up the 20th growth ring. A similar trend occurs for P. taeda and P. patula (Palermo et al., 2013). Thus, all the 12-year old trees used presented either juvenile or transition wood, of lower density and, consequently, lower mechanical strength.

There are no minimum requirements for the PVP panel properties evaluated in this study. However, MOR of 74.49 MPa, MOE of 5338.95 MPa and glue line shear strength of $2.67 \mathrm{MPa}$ for PVP were found for Pinus oocarpa panels with $663 \mathrm{~kg} / \mathrm{m}^{3}$ basic density (Lima et al., 2013). Values of $43.6 \mathrm{MPa}, 3944 \mathrm{MPa}$, $1.81 \mathrm{MPa}$ and $460 \mathrm{~kg} / \mathrm{m}^{3}$ for parallel MOR, parallel MOE, glue line shear strength and density of panels produced with $P$. taeda veneers on the surface and Schizolobium amazonicum (paricá) in the core were also reported (Iwakiri et al., 2010). A relationship between the density and mechanical strength of the panel can be observed by comparing the values obtained in this study.

The parallel and perpendicular MOE and MOR values, confirm the balance effect in plywood panels. On the other hand, adapted PVP panels showed different strength and stiffness values in perpendicular and parallel directions.

Pinus taeda showed higher mechanical strength than $P$. patula panels when urea-formaldehyde adhesive was used with this trend changing when phenol-formaldehyde was applied. This was attributed 
to the density variations of the panels. The $P$. patula panels presented lower density with urea-formaldehyde and higher density with phenol-formaldehyde (Table 3). Therefore, there is a direct relationship between panel density and resistance.

\section{CONCLUSIONS}

All panels have properties compatible with those required by ABIMCI, except for the apparent density. The adapted PVP panels presented differences in the mechanical properties between axial and tangential directions and the comparison of parallel and perpendicular MOE and MOR values confirms the balance effect in plywood panels.

When bonded with urea-formaldehyde, Pinus patula panels showed lower strength, stiffness and density than $P$. taeda panels. The reverse trend occurred in panels glued using phenol-formaldehyde.

12-year-old Pinus patula panels showed adequate physical and mechanical properties, independent of the adhesive and veneer arrangement, demonstrating the potential of this species for panel production.

\section{ACKNOWLEDGEMENTS}

The authors would like to thank the CAPES, Coordination for the Improvement of Higher Education Personnel - Brazil (Finance Code 001); the UNICENTRO, Midwestern State University and REMASA, Reforestation for the support received to carry out this work.

\section{SUBMISSION STATUS}

Received: 29 apr., 2019

Accepted: 13 nov., 2019

\section{CORRESPONDENCE TO}

\section{Everton Hillig}

Programa de Pós-graduação em Ciências Florestais, Universidade Estadual do CentroOeste - UNICENTRO BR 153 Km 07, CEP 84500-000, Irati, PR, Brasil E-mail: ehillig@unicentro.br

\section{FINANCIAL SUPPORT}

Coordenação de Aperfeiçoamento de Pessoal de Nível Superior (Grant 001/Scholarship), REMASA Reflorestadora S/A, (Grant 000/Material support), UNICENTRO, (Grant 000/Technical support).

\section{REFERENCES}

Aguiar AV, Sousa VA, Shimizu JY. Espécies de pinus mais plantadas no Brasil. In: Aguiar AV. Cultivo de pinus. 2. ed. Brasília: Embrapa Florestas; 2014. 13 p. (Sistema de Produção, no. 5).

Almeida DH, Ferro FS, Varanda LD, Souza AM, Icimoto $\mathrm{FH}$, Christoforo AL et al. Quality control in plywood manufacturing: physical properties of commercial plywood of Pinus sp. International Journal of Composite Materials 2013; 3: 163-167. http://dx.doi.org/10.5923/j. cmaterials.20130306.04.

Almeida NF, Bortoletto G Jr, Mendes RF, Surdi PG. Produção e avaliação da qualidade de lâminas de madeira de um híbrido de Pinus elliottii var. elliottii $\times$ Pinus caribaea var. hondurensis. Floresta e Ambiente 2014; 21(2): 261-268. http://dx.doi.org/10.4322/floram.2014.022.

Associação Brasileira da Indústria da Madeira Processada Mecanicamente - ABIMCI. Compensado de pinus. Curitiba: ABIMCI; 2002. 24 p. (Catálogo Técnico, no. 1).

Aydin I, Çolak S, Çolakoğlu G, Salih E. A comparative study on some physical and mechanical properties of laminated veneer lumber (LVL) produced from Beech (Fagus orientalis Lipsky) and Eucalyptus (Eucalyptus camaldulensis Dehn.) veneers. Holz als Roh- und Werkstoff 2004; 62(3): 218-220. http://dx.doi.org/10.1007/s00107004-0464-3.

Campos CI, Morais RDV, Nascimento MF. Caracterização físico-mecânica de painéis de madeira compensada produzidos com Pinus sp. e resina poliuretana bicomponente. Madeira: Arquitetura e Engenharia 2009; 10(24): 37-50.

Costa MA, Del Menezzi CHS. Effect of thermo-mechanical treatment on properties of parica plywoods (Schizolobium amazonicum Huber ex Ducke). Revista Árvore 2017; 41(1): e410115. http://dx.doi.org/10.1590/1806-90882017000100015.

Folmann WT, Miranda GM, Dias AN, Moro FC, Fernandez MLQ. Viabilidade de projetos florestais em três regimes de manejo na mesorregião centro-oriental do Paraná. Floresta 2014; 44(1): 153-160. http://dx.doi.org/10.5380/ rf.v44i1.30096.

Guimarães JB Jr, Protásio TP, Mendes RF, Mendes LM, Guimarães BMR, Siqueira HF. Qualidade de painéis LVL produzidos com madeira de clones de Eucalyptus urophylla. Pesquisa Florestal Brasileira 2015; 35(83): 307-313. http:// dx.doi.org/10.4336/2015.pfb.35.83.797. 
Iwakiri S, Matos JLM, Pinto JA, Viana LC, Souza MM, Trianoski $\mathrm{R}$ et al. Produção de painéis laminados unidirecionais - PVP com lâminas de Schizolobium amazonicum, Eucalyptus saligna e Pinus taeda. Cerne 2010; 16(4): 557-563. http://dx.doi.org/10.1590/S010477602010000400015 .

Iwakiri S, Olandoski DP, Leonhardt G, Brand MA. Produção de chapas de madeira compensada de cinco espécies de pinus tropicais. Ciência Florestal 2001; 11(2): 71-77. http://dx.doi.org/10.5902/198050981656.

Iwakiri S, Sanches FG, Potulski DC, Silva JB, De Andrade M, Marchesan R. Avaliação do potencial de uso de espécies de Pinus tropicais e Eucalipto na produção de painéis compensados ureicos. Floresta 2012; 42(2): 277-284. http://dx.doi.org/10.5380/rf.v42i2.20657.

Liebsch D, Moreira JMMÁP, Oliveira EB, Mikich SB. Impacto do descascamento de árvores de Pinus taeda L. por macacos-prego na produção e receita em plantios com desbastes. BIOFIX Scientific Journal. 2018; 3(1): 48-55. http://dx.doi.org/10.5380/biofix.v3i1.56574.

Lima NN, Mendes LM, Sá VA, Bufalino L. Propriedades físico-mecânicas de painéis PVP produzidos com três espécies amazônicas. Cerne 2013; 19(3): 407-413. http:// dx.doi.org/10.1590/S0104-77602013000300007.

Melo RR, Del Menezzi CHS. Influence of veneer thickness on the properties of LVL from Paricá (Schizolobium amazonicum) plantation trees. European Journal of Wood and Wood Products 2014; 72(2): 191-198. http://dx.doi. org/10.1007/s00107-013-0770-8.

Mendoza ZMSH, Borges PHM, Santos EA, Penna JE, Elias MPS, Morais PHM. Estudo comparativo das propriedades físicas e mecânicas de painéis compensados e laminated veneer lumber (LVL). Nativa (Sinop) 2017; 5: 588-593. http://dx.doi.org/10.5935/2318-7670.v05nespa19.

Müller MT, Haselein CR, Melo RRD, Stangerlin DM. Influência de diferentes combinações de lâminas de Eucalyptus saligna e Pinus taeda em painéis PVP. Ciência Florestal 2015; 25(1): 153-164. http://dx.doi. org/10.5902/1980509817473.

Palermo GPM, Latorraca JVF, Severo ETD, Nascimento AM, Rezende MA. Delimitação entre os lenhos juvenil e adulto de Pinus elliottii Engelm. Revista Árvore 2013; 37(1): 191-200. http://dx.doi.org/10.1590/S010067622013000100020 .
Purba CYC, Pot G, Viguier J, Ruelle J, Denaud L. The influence of veneer thickness and knot proportion on the mechanical properties of laminated veneer lumber (LVL) made from secondary quality hardwood. European Journal of Wood and Wood Products 2019; 77(3): 393-404. http://dx.doi.org/10.1007/s00107-019-01400-3.

Ross RJ. Wood handbook: wood as an engineering material. Wisconsin: USDA; 2010.509 p. General Technical Report Fpl-gtr-190.

Sánchez-González A. Una visión actual de la diversidad y distribución de los pinos de México. Madera y Bosques 2008; 14(1): 107-120. http://dx.doi.org/10.21829/ myb.2008.1411222.

Santiago-García W, Los Santos-Posadas D, Manuel H, Ángeles-Pérez G, Valdez-Lazalde JR, Corral-Rivas JJ et al. Modelos de crecimiento y rendimiento de totalidad del rodal para Pinus patula. Madera y Bosques 2015; 21(3): 95-110.

Silva BCD, Vieira MC, Oliveira GDL, Gonçalves FG, Rodrigues ND, Lelis RCC et al. Qualidade de compensados fabricados com adesivos à base de tanino-formaldeído de Pinus oocarpa e fenol-formaldeído. Floresta e Ambiente 2012; 19(4): 511-519. http://dx.doi.org/10.4322/floram.2012.057.

Tenorio C, Moya R, Muñoz F. Comparative study on physical and mechanical properties of laminated veneer lumber and plywood panels made of wood from fastgrowing Gmelina arborea trees. Journal of Wood Science 2011; 57(2): 134-139. http://dx.doi.org/10.1007/s10086010-1149-7.

Van Zonneveld M, Jarvis A, Dvorak W, Lema G, Leibing C. Climate change impact predictions on Pinus patula and Pinus tecunumanii populations in Mexico and Central America. Forest Ecology and Management 2009; 257(7): 1566-1576. http://dx.doi.org/10.1016/j.foreco.2008.12.027.

Vidaurre G, Lombardi LR, Oliveira JTS, Arantes MDC. Lenho juvenil e adulto e as propriedades da madeira. Floresta e Ambiente 2011; 18(4): 469-480. http://dx.doi. org/10.4322/floram.2011.066.

Vieira MC, Brito EO, Gonçalves FG. Evolução econômica do painel compensado no Brasil e no mundo. Floresta e Ambiente 2012; 19(3): 277-285. http://dx.doi.org/10.4322/ floram.2012.033.

Wilson JB, Dancer ER. Gate-to-gate life-cycle inventory of laminated veneer lumber production. Wood and Fiber Science 2005; 37(N. esp.):114-127. 